Article

\title{
Educating for Public Happiness and Global Peace: Contributions from a Portuguese UNESCO Chair towards the Sustainable Development Goals
}

\author{
Helena Águeda Marujo ${ }^{1, *(1)}$ and Mafalda Casais ${ }^{2}$ \\ 1 Centre for Public Administration and Public Policies (CAPP), Instituto Superior de Ciências Sociais e \\ Políticas (ISCSP), Universidade de Lisboa, 1300-663 Lisboa, Portugal \\ 2 Centre for Research in Architecture, Urbanism and Design (CIAUD), Lisbon School of Architecture (FAUL), \\ Universidade de Lisboa, 1349-063 Lisboa, Portugal; mafaldacasais.ciaud@fa.ulisboa.pt \\ * Correspondence: hmarujo@iscsp.ulisboa.pt
}

check for updates

Citation: Marujo, H.Á.; Casais, M. Educating for Public Happiness and Global Peace: Contributions from a Portuguese UNESCO Chair towards the Sustainable Development Goals. Sustainability 2021, 13, 9418. https:// doi.org/10.3390/su13169418

Academic Editors:

Francisco Zamora-Polo and Jesús Sánchez Martín

Received: 23 May 2021

Accepted: 18 August 2021

Published: 22 August 2021

Publisher's Note: MDPI stays neutral with regard to jurisdictional claims in published maps and institutional affiliations.

Copyright: (c) 2021 by the authors. Licensee MDPI, Basel, Switzerland. This article is an open access article distributed under the terms and conditions of the Creative Commons Attribution (CC BY) license (https:/ / creativecommons.org/licenses/by/ $4.0 /)$.

\begin{abstract}
For a positive global future, it is fundamental to tackle the existing web of psychological, economic, sociological, and cultural processes reflected in current education systems. Confronted with complex issues that are essential to the stability of civilizations, we need more voices addressing a critical analysis of education in its key role. This can result in more people participating as happy, informed, and engaged citizens. This paper introduces the argument for education to promote public happiness (Felicitas Publica) and support global peace, addressing the attainment of the Sustainable Development Goals (SDGs) \#3, \#4, and \#16. It begins by mapping the landscape of promising education-related practices supporting these SDGs and provides recommendations for research and actions. In addition, it presents the work of the UNESCO Chair on Education for Global Peace Sustainability, based at the Universidade de Lisboa, in Portugal, as an illustrative example. With this paper, we hope to convey the input of different branches of psychology that have the common good as their aim and address the positive transformation of our current educational processes.
\end{abstract}

Keywords: education; psychology; SDGs; peace; public happiness

\section{Introduction}

For decades, issues in education have been conceived of as merely didactic or pedagogic, and mainly supported by studies in psychology. These studies addressed content (what to teach) and methods (how to teach) [1]. It took years to address the conditions of education beyond the classroom — such as the household, social background, equality of opportunities, and society at large. When questioning structural reforms of the school and curricula, the debate also introduced a broader perspective. Consequently, education came to be understood as an asset in national and international development. This standpoint endorsed studies on how education delivers economic profits to both the individual and society [2]. We can identify several paradigms of education-behavioral, cognitive, humanistic, cognitive-constructivist, social-constructivist, transformative, etc.-constantly evolving in ways that influence its purpose, design, practice, and policies [1].

Quality education promotes knowledge and inventiveness and guarantees the acquisition of foundational skills-such as literacy, numeracy, analytical problem solving-and different high-level, abstract, and reflexive rational skills [3]. However, there is a need for an education paradigm that develops interpersonal, emotional, and social skills, and the abilities, values, and attitudes that qualify citizens to experience healthy and happy lives. This paper wants to contribute to the transformative paradigm, which positions learners and teachers as participants in knowledge conception, empowering them to see their place in the world through an ethical lens, and therefore, prepared to challenge the status quo as agents of change [4]. 
The question raised here is "how can we design and implement formal and informal educational processes committed to a greater good?". This paper supports the argument for a transformative education paradigm that goes beyond one of transmission of knowledge. It defends the promotion of public happiness (Felicitas Publica) and global peace as complementary dimensions enabling that specific realization and those of the Sustainable Development Goals (SDGs). Data from diverse subdisciplines of psychology-positive psychology, educational psychology, community psychology, social psychology, peace psychology, political psychology-support this. The paper discusses the 2030 Agenda for Sustainable Development and its associated projects and goals concerning education; specifically, it looks at SDG \#3 (ensure a healthy life and promote wellbeing for all at all ages), SDG \#4 (ensure quality, inclusive, and equitable education and promote lifelong learning opportunities for all), and SDG \#16 (promote peaceful and inclusive societies for sustainable development, provide access to justice for all, and build effective, accountable, and inclusive institutions at all levels), discussing them in relation to education. To illustrate the selected SDGs, the paper presents a UNESCO Chair ongoing at the Universidade de Lisboa, attending to its scope, purposefulness, and values. Lastly, the paper addresses specific educational targets and models we consider as valid paths for attaining individual and social assets, ending with conclusions and proposals for a future research agenda.

\section{Literature Review: Contextualization}

\subsection{The 2030 Agenda for Sustainable Development and the SDGs}

The United Nations (UN), in its General Assembly of 25 September 2015 [5], established the 2030 Agenda for Sustainable Development. The agenda included 17 SDGs with 169 targets, in an ambition to institute a plan of action to promote world peace, the eradication of poverty, the protection of the planet, human rights for all, gender equality, and sustainable development in its three dimensions: social, economic, and environmental.

Education is at the heart of the 2030 Agenda for Sustainable Development, and it is essential for the success of all SDGs. It can accelerate the achievement of each goal. After analyzing the progress made towards the Education for All (EFA) Monitoring Report (2015) [6], the education-related Millennium Development Goals (MDGs), the declaration of the United Nations Decade of Education for Sustainable Development (2005) [7], the more recent Global Action Program on Education for Sustainable Development (ESD) (2014), and the Incheon Declaration and Framework for Action (2015) [8], we find it unquestionable that great progress has been made in the past 20 years. Nevertheless, it is also clear that the world is still far from reaching the established aims of transforming lives through education.

After examining the UNESCO project Futures of Education, on how knowledge and learning can shape the future of humanity and the planet [9], and exploring the World Economic Forum education program (WEF) [10], dedicated to defining new and promising quality models of education for the Fourth Industrial Revolution, we can identify a tendency to use a competencies framework and a future-oriented perspective of education. Both intend to promote "personal, interpersonal and project-oriented skill-building and growth" [11] (p. 15). Furthermore, in the UNICEF Education Strategy Every Child Learns 2019-2030 [12] (p. 4), it is stated that "The gap between the levels of learning that education systems are providing and what children, communities and economies need, is growing. The breadth and depth of this learning crisis provides the greatest global challenge to preparing children and adolescents for life, work and active citizenship". In parallel, the Global Compact on Education (2019) [13], promoted by the Vatican and Pope Francis, aims to create a global alliance for the future of humanity, as much as for our common home. In the launch of the project, Pope Francis highlighted that "Never before has there been such need to unite our efforts in a broad educational alliance, to form mature individuals capable of overcoming division and antagonism, and to restore the fabric of relationships for the sake of a more fraternal humanity" [14]. 
Although the world has made some extraordinary improvements in education since 2000 - when the six Education for All (EFA) objectives and the Millennium Development Goals (MDGs) [15] were founded-unfortunately, those goals were not attained by the 2015 deadline. More recently, and regrettably, the global health pandemic risks to wipe out several decades of progress. As a consequence, insistent action is required to achieve the uncompleted program.

Among the 17 SDGs, this paper highlights three goals of extreme importance towards this urgent educational agenda: \#3,\#4, and \#16.

SDG \#3-Ensure a healthy life and promote wellbeing for all at all ages. As indicated in the SDG Compass, "Health is a fundamental human right and a key indicator of sustainable development. Poor health threatens the rights of children to education, limits economic opportunities for men and women and increases poverty within communities and countries around the world" [16]. With the urgency and seriousness of major physical health issues, promoting wellbeing-a topic present in this SDG-is undervalued. Furthermore, the pervasiveness of mental disorders is on the rise amid the populations of Western developed countries, e.g., [17]. In addition, a robust association has been found between physical and mental health, e.g., [18]. Behavioral and emotional issues impact the learning process in the younger generation, threating the equitable and inclusive education targets. While the link between positive education and SDG \#3 is apparent, there is room for improvement towards a more eudaimonic view of wellbeing. Further in the text, we explore what actions are being taken in this regard.

SDG \#4-Ensure quality, inclusive and equitable education and promote lifelong learning opportunities for all. Education is a fundamental human right and is indispensable for the achievement of sustainable development. It is only possible to empower girls, combat climate change, fight inequality, and end extreme poverty through education. In this paper, special attention is given to sub-goal \#4.7, as "providing access to quality education breaks the cycle of poverty, reduces inequalities between genders, races and religious beliefs, and promotes tolerance for world peace" [16]. This goal, and particularly its subgoal, can contribute to public happiness and to peace, which we will discuss further in the next sections concerning the actions being taken.

SDG \#16-Promote peaceful and inclusive societies for sustainable development, provide access to justice for all and build effective, accountable and inclusive institutions at all levels. Education, business, social cohesion, and the emergence of social solutions for new challenges, "all thrive in peaceful environments with effective institutions where operating practices are predictable, human relations are dignifying and environments are stable" [16]. Peace education is a fundamental topic that we will also discuss in the following sections, particularly linking it to relational and collaborative learning.

As an illustrative and practical example, we will present the UNESCO Chair on Education for Global Peace Sustainability (E=GPS) situated at the Universidade de Lisboa, since it is a project that tries to epitomize values and pragmatics of the transformative approach to education, where collective and individual wellbeing, far-reaching educational approaches, and peace are addressed. Furthermore, we will debate different approaches to education as transformative action-oriented for the common good, in propositions centered around non-academic competencies. All are supported by psychological research, although they might also integrate other scientific domains.

\subsection{The Transformational Learning Paradigm}

Transformative experiences lead us to think differently and can also modify our beliefs and worldviews [19]. Transformational learning is conceptualized as involving a fundamental change in frames of reference, considering people as free and accountable. Furthermore, it reflects knowledge as well as individual and social concepts, and believes in a liberal democratic society focused on construing meaning from experience as a guide to action [20]. Transformational learning includes three dimensions: psychological (changes in understanding of the self), convictional (revision of belief systems), and behavioral 
(changes in lifestyle) [21]. The transformational perspective on education needs to go further, advancing beyond an emphasis on individual agency and considering the context, values, and the social systems in which the learners are imbedded, as well as the link between meaning and practice [20].

Debates addressing the role of emotions, social contexts and relationships, cultural connections, and creativity, in general, continue to influence the progress of the transformational learning theory [22]. Faced with the current societal challenges, these diverse paradigms and scientific debates give us an opening to monitor the dominant models of learning and teaching. In addition, they allow us to revisit the goals of education for the 21st century and to build not just human capital for economic growth but to create global citizens for universal happiness. This implies making conscious and virtuous decisions, and to act responsibly and ethically to deal with today's personal, local, and global challenges. As described in the United Nations Educational, Scientific and Cultural Organization (UNESCO) Roadmap for Implementing the Global Action Program on ESD [23] (p. 7): "To create a world that is more just, peaceful and sustainable, all individuals and societies must be equipped and empowered by knowledge, skills and values as well as be instilled with a heightened awareness to drive such change".

A fundamental reason behind this aim of rethinking education is that the mere logic of finance, profitability, productivity, and preparation for the job market is not adequate and sufficient per se. It has been corroding the construction of virtuous ethic and radical humanity in the education and training domains [24]. Therefore, most of the current educational values and processes are not supportive- or are even detrimental — to attaining the SDGs. These should be regarded as an instrument for individual and collective empowerment, leading to new intuitions, visions and solutions, and better actionability [11].

Contemporary developed societies and pedagogical methods are mainly rooted in fierce individualism [25]. Current educational politics and practices are embedded in a certain understanding of the self and human ontology, as well as in normative preconceptions of what the formal and informal educational processes imply [26]. The person is, therefore, considered as a separate entity that is completely self-sufficient, disconnected from the context, and driven by egoistic motives [27]. These assumptions, if unaddressed, may continue to give rise to an ideology that constrains our appreciation of different realities, menacing the respect and honor of the diversity of human experience.

Another reason behind this aim of rethinking education is that, in the decision-making processes, regulations, and subsequent socio-political, economic, and pedagogical practices (test-driven, programed for good end results, profit-oriented, meritocratic, socially anemic), education and training are treated not as investment goods (assets), but as consumption goods (costs) [28]. A further reason is that we are seeing the unprecedented emergence of narratives about the need of a paradigm shift in the educational territory: new proposals, platforms, manifestos, and pedagogical models echo and corroborate each other's grounds and values. These visions resonate with claims to articulate the value of the educational efforts within a broader humanistic context that makes it more relevant to present-day society's needs and goals. Several of these propositions defend the interplay between education and the hopeful 2030 Agenda and its 17 SDGs. These projects recognize the central role of education in the improvement and preparation of future citizens and in the keeping of democracy, and have in common the fact that they develop in networks, advocate participatory organizing tools along with new technologies, and integrate distinct groups and requests. They are often consolidated through horizontal, democratic, intergroup, and systemic processes [29]. 


\section{Method}

To advance education in a transformative direction, a UNESCO Chair was created at the Universidade de Lisboa: the UNESCO Chair on Education for Global Peace Sustainability (E=GPS). It is a four-year project, renewable each year, and validated by the UNESCO Headquarters in 2018. E=GPS has been a path to articulate narratives and practices devoted to the 2030 Agenda. It brings together within its competences four main lines of action: applied scientific research, advanced education and training, praxis innovation, and dissemination. It is a participatory and co-constructed project that seeks to promote scientific and practical approaches to the complexity of peace, wellbeing, quality of life, and education, at various levels: individual, collective, national, and international. Therefore, it implies close collaboration among diverse national and international stakeholders [30].

The key objectives of the E=GPS include [31]:

- Innovative and inclusive education and training (throughout online learning, teacher's training, school interventions, and postgraduate courses);

- Supervised practices through workshops and laboratories;

- $\quad$ Running of observatories aimed at identifying resources and needs;

- Creation, monitoring, and evaluation of practical tools for education (games, mobile applications, etc.);

- $\quad$ Fostering of research practices;

- Co-construction and dissemination of knowledge;

- Celebrating good practices (in research, publication, and action);

- Encouraging multidisciplinary relationships among several domains-culture, arts, humanities, social and political sciences, education, technology and the media.

Its principles defend that every intervention has diverse stakeholders in co-creation. They intend to (1) bring hope to people regarding the future; (2) be action-oriented, while also thought-provoking; (3) be marked by dialogue, collaborative and participative, evoking horizontal relationships and co-leadership; (4) create networks supported in diversity and inclusion; (5) involve scientific foundations and action-research methods; (6) bring a critical stance regarding the status quo in education through creative and innovative approaches; and (7) serve the local communities while spread globally [30-32]. Overall, the project has been involved (by 2021) in 54 conferences, webinars, and workshops; 10 training programs; and the organization of two books and six book chapters, among other outcomes.

As previously mentioned, the project aspires to deal with the future of education through different approaches, all targeted at SDG \#4, but also encompassing SDG \#3 and SDG \#16. In the following sections, we specify how we addressed each goal by providing examples of the E=GPS project and the description of some of the actions taken therein.

\section{Analysis of Pre and Post-Training of the "Positive Education" Course}

The research hereby presented, selected from among other research projects included in the E=GPS, was carried out in the phenomenological design of qualitative research methods. The study group consisted of 84 teachers who completed three editions of courses on "Positive Education", devoted to enhancing knowledge and behavior change on the domains of peace and public happiness. In between training sessions (in a total of five), teachers were asked to implement projects or initiatives associated with public happiness and positive peace. The first edition of the course involved 30 teachers $(85 \%$ female, average age of 44$)$, the second edition included 36 teachers $(75 \%$ female, average age of 52), and the third edition included 18 teachers (90\% female, average age of 47 ). Teachers explained the concepts of peace and public happiness before the beginning of the course, indicating what they were implementing in their personal life and work to put both into practice. After $15 \mathrm{~h}$ of an online training on those topics, using science as a rigorous basis for diverse practical approaches and proposals_-addressing themes such as relational goods, compassion, empathy, character strengths, non-violent communication, eudaimonic and hedonic happiness, and global citizenship, among others-the teachers were asked to again explain the same concepts and describe eventual new practices, 
implemented as a consequence of the training (Appendix A). A comparative content analysis of the pre-training and post-training concepts' explanation and implementation in daily and professional life allowed us to identify changes in concept definition and also in practice implementation (Appendix B). In the following sections, we present this study's contextualization and results in more detail.

\section{The Quest for Individual and Collective Wellbeing: Addressing SDG \#3 \\ 4.1. Positive Education as a Path to Mental and Physical Health}

Neoliberalism affects the telos of education by redefining its meaning and commodifying its central value. It accentuates transferable skills and competencies, while disregarding non-monetary values, indispensable in enduring a healthy democratic society [33,34]. Under this model, economic growth is undebatable and obtained at the expense of the quality of the relational and ecological environment, therefore bringing a potential negative effect on individual and collective happiness [35,36]. Positive education is trying to tackle this issue. Defined as the incorporation of positive psychology into education models, it is the combination of traditional education principles and academic success with the study and optimization of happiness and wellbeing [32]. In particular, the movement embraces the implementation of happiness models and a "character strengths" approach. A school curriculum that includes psychological wellbeing will enhance the possibilities to prevent depression, increase life satisfaction, boost social responsibility, uphold creativity, and enhance resilience, while raising academic success [37]. Regarding character strengths, education has long been nurturing positive virtuousness growth [38]. Yet, only after the publication of "Character Strengths and Virtues: A Handbook and Classification" by Peterson and Seligman [39], the endorsement of character strengths began providing a cross-cultural relevant framework "for educating the heart" [40] (p. 65). Until then, the programs derived from the partiality of cultural, religious, or political perspectives [41].

Education is certainly considered as a key engine of economic growth and social mobility, and it has been associated with many personal and social welfare paybacks, namely greater income, improved health, and better longevity, e.g., [28]. It is considered a critical feature that defines the productivity of a country [28,42]. Although the prevailing research on the relation between education and happiness has produced a mixed list of findings [43], education seems to be positively correlated with subjective wellbeing and has been associated with superior happiness [28]. It has shown that subjective wellbeing helps forecast social behaviors that others value - for instance, individuals with higher happiness scores are subsequently more generous when deciding how much money to give to others; equally, happier individuals volunteer more [44]. Flavin and Keane [45] underline a relationship between subjective wellbeing and political participation. Moreover, De Neve and colleagues [46] note that happier people are, in general, more cooperative and more sociable.

Proven links between wellbeing and social relationships include minor rates of anxiety and depression, greater self-esteem, higher empathy, better resilience, and more trusting and cooperative affiliations [28]. Healthy and harmonious relationships can also benefit the immune system and may even contribute to a longer life expectancy [46]. Wellbeing and mental health are, therefore, a central theme, from the point of view of the individual, but also from the perspective of the human systems where they participate. Defined as "a state of wellbeing in which every individual realizes their own potential, can cope with the normal stresses of life, can work productively and fruitfully, and is able to make a contribution to their community" [12], mental health is directly addressed by the positive education movement and by positive psychology.

The link between positive education and SDG \#3 is, therefore, clear. Nevertheless, there is room for improvement inside this movement to go beyond a more individualistic, hedonic, and intrapsychic perspective and embrace a systemic and eudaimonic view of wellbeing. There is already a tendency inside the subdiscipline of positive psychology towards that direction [31]. Recently, positive psychology has moved into its Third Wave (the First focused research on strengths instead of weaknesses and disease; the Second 
was about embracing the negative while potentiating the positive). This more recent Third Wave is now paying attention to the happiness of sociality [47-49].

\subsection{Relational Goods and Public Happiness: From Individual to Collective Wellbeing}

Beyond the disagreement over definitions of what happiness is, philosophers and researchers generally agree that happiness is something that matters to us from a subjective perspective [50]. More recently, happiness has been addressed from the perspective of the citizen, or the person in relation. Public happiness/Felicitas Publica includes elements from Latin economic perspectives, namely the Italian movement of Civil Economy. Felicitas, the Latin word for a life of value, has an etymology that implies fertility and virtuousness. Felicitas is, therefore, a common good mediated by relational goods and by the ethos of the market [51].

The complex concept of Aristotelic eudaimonia is the root of public happiness [51]. It has a "social" nature, and it is a result of the practice of virtues. Interpreted and translated as "human flourishing", eudaimonia means the fulfilment of the genuine and good nature of the person. Such fulfilment is not reached by pursuing individual and hedonic happiness, but only reached within the context of community-the Greek polisand requires participation in the civil and political life of the city. It also implies friendship, where fraternal, reciprocating, and gratuitous elements emerge. Hence, only in the polis, and only within friendship, can a person accomplish their inner purpose (telos) and be ethical and virtuous.

This relational model, an alternative to the more individualistic, Anglo-Saxon, and hedonistic wellbeing approaches, is complementary of the Stoic appropriation theory, specifically linked to the Greek concept of oikeiosis (in Latin: conciliatio, conciliation). Oikeiosis is ingrained in the term oikos, the Greek word for house, family, or household, and is an element of words such as economics, oikonomics, and ecology. It arouses the awareness of being "at home" and implies a sense of belonging. It is sketched on concentric circles, linking the non-alienated self-acceptance with two other spheres of human action: the first is significant others (family members, friends, colleagues), and the second is the polis. The social ethics and responsibility that bound the individual life of the non-alienated person with the civic life is, therefore, at the heart of the theory. The remoteness from the center is a standard by which we can quantify the strength of our ties and duties towards other fellow members of the community [30,32,52].

The concept of public happiness brings us to the concept of relational goods. They have been defined as non-instrumental interpersonal relations, that is, the affective/expressive side of interpersonal relationships [25,35,51]. Relational goods can only be enjoyed jointly with other co-participants (unlike conventional goods), are characterized by intrinsic attributes, and cannot be exchanged through markets [53]. Therefore, the concept refers to one's quantity and quality of relational experience with other people and concerns relationships that are intrinsically motivated [54]. The quality of genuineness of relational goods is also relevant, since the relationship is the reward itself. If we fake sympathy or empathy, we lose the non-instrumental value of these goods [55]. Trusting others is a good example of the universal public benefits of relational goods [56], and of the value of the coordination needed to produce a social event.

Although education is essentially a social activity, the delivery of learning and teaching processes is frequently one based on solipsism (the theory that only the self exists), and participants-and their performance-are mostly considered in isolation. The activity itself is conveyed and experienced as a consumption good, and can be considered an instrumental social event, since the market is the medium through which the activity is implemented (either in the private or the public educational context). Apart from being an economic transaction, with a clear aim towards an extrinsic goal (having good grades, finding a good job, earning good money, having an upright social standing), student or school rankings and other kinds of educational competition became the product of market forces [57]. Bringing forward the interpersonal dimension of the economic reality of education, and foreseeing schools, classrooms, recess spaces, teacher-student and 
teacher-parent relationships as interdependent and non-instrumental, puts the focus on the relevance of the quality of the "encounter" [57].

The recent concept of relational welfare is also worth mentioning here. "Relational welfare is a human-centered and collaborative approach premised on human rights, social justice and societal sustainable development. Relational welfare means that welfare is a resource that people co-create together, where personal and collective relationships and environments are placed at the center of development. The objective of relational welfare is enabling wellbeing for all throughout empowering and capacity enhancement-in people, amid people, in communities and organizations-by involving private, public, and civil players to cooperate and share all kinds of capitals, from knowledge to material resources. Hence, relational welfare interventions imply a communal mission across actors, sectors, and organizations, endowing whole-of-society tactics and a collective impact" [58] (p. 36). These perspectives bring a common-good point of view to SDG \#3, with implications for a healthy and happy life for all and for educational practices.

\subsection{Examples from the E=GPS to Address SDG \#3}

The E=GPS program has implemented diversified initiatives conducive to the optimization of wellbeing, mental health, public happiness, and relational goods. One was the implementation of research projects on organizational compassion, hope, optimism, and Felicitas Publica, with dissemination of data and public action initiatives through scientific and non-scientific publications and media-books, papers, webinars, videos, international solidarity projects, radio and TV shows, social media. Another example was the implementation of dialogic moments inside schools and in diversified communities, along with training programs and webinars for teachers and educators working in Portugal and Brazil. They focused on the topics of positive education, optimism and hope, compassion, public happiness, and social capital. These initiatives had practical outcomes in the school and involved hundreds of educators so far-and are now being prepared to reach thousands. In addition, an initiative on the topic of public happiness involved the majority of the eighteen Schools of the Universidade de Lisboa, whose insights were translated into scientific literature [30].

Among the encounters promoted within the project, we highlight two webinars: (1) a webinar on "Training for Mental Health-Special Edition on Higher Education" and (2) a webinar on "The art of being light: proposals for positive lives in challenging times". Moreover, we point out the "Happiness, Education and Relational Goods" event, a remote conference which took place on July 2020, within the scope of the international Vatican project "Economy of France" and the School of Civil Happiness in Italy.

The course on Positive Education (mentioned in the Method Section) involved teachers from kindergarten to university levels. Apart from the specific contents on peace and public happiness, the pedagogical processes behind the training were themselves an operationalization of the contents, serving as empirical experience of the coherence between the topics being presented and the educational processes to deliver them. Namely, these were investing in participative and collaborative methods, in the practice of empathy, trust and emotional expression, and in empowering, community, and capacity building. Results of the content analysis of the written individual responses of 84 teachers before and after the training on Positive Education showed an increased relevance attributed to the building of competencies for peace and public happiness (e.g., empathy, compassion, justice and equity, non-violent communication, mutual respect, caring for the common good, investment in positive, inclusive and trusting relationships). Additionally, the impact of the course provoked the development of the implementation in the school context of a larger range of innovative initiatives dedicated to global citizenship and democratic behaviors, which are part of SDG \#4. 


\section{Global Citizenship and Democratic Education: Addressing SDG \#4 and Sub-Goal \#4.7}

In addition to addressing the SDG \#3, this paper also focuses on goal \#4, and in particular, on its sub goal \#4.7. Goal \#4 contains 10 specific aims to achieve quality education, defending the idea of lifelong learning for all-and equitable and inclusive education. When facing this broad educational goal, Nikel and Iowe [59] proposed seven conceptual dimensions to describe quality education: effectiveness, efficiency, equity, responsiveness, relevance, reflexivity, and sustainability. These authors [59] presented the concept of excellence in education as a "fabric", indicating that balancing these seven dimensions, maintaining all of them under pressure, and intertwining them at different systemic levels would elevate the quality of learning. Additionally, in the lifelong learning perspective, learning is about the development of the whole person, indicating a combination of individual and collective social, civic, financial, and political consequences that are required in a particular setting [60]. Sub-goal \#4.7 aims to ensure that, by 2030, all leaners acquire the knowledge and skills needed to promote sustainable development and global citizenship. This includes, among others, education for sustainable lifestyles, human rights, gender equality, promotion of a culture of peace and non-violence, support for democracy, and appreciation of cultural diversity. Probably more than any other target, sub-goal \#4.7 addresses the humanistic, collective, and moral purposes of education, and explicitly links education to other SDGs, capturing the transformative ambitions of this global agenda.

Growing globalization and the high principles of citizenship helped formulate the Global Citizenship Education (GCE) principles [61]. GCE calls for the organization of curricular activities around the subject and is one of the most strategic spheres of UNESCO. This is the focus of sub-goal \#4.7, indispensable to meet the SDG \#4. As such, this target 4.7 is somehow inclusive of the previously presented contents. Addressed in its wideencompassing vision, it can contribute, directly and indirectly, to public happiness and to peace, through the very best of citizenship education.

Hence, global citizenship is especially important for addressing problems on climate change, use of natural resources, food systems, participatory politics, and democracyproblems that have complex scopes, such as deep value divergences, high levels of uncertainty, catastrophic threats, and considerable expenses linked with all kinds of mistakes [62,63].

Democracy implies certain values - such as equality, social justice, freedom, solidarity, communitarian engagement- that treasure harmony upon diversity, provide social cohesion, and safeguard the rights of everyone in our current multicultural societies $[64,65]$. The endangering of democracies and of a sustainable common future, where conflicts of all kinds put at risk the possibility of peaceful societies, and of ecological diversity and sustainability, is igniting new processes inside the global citizenship education movement, and giving special attention to peace processes [63]. GCE is, therefore, a master piece to promote a future-oriented quality and lifelong education.

If there is no doubt that education can act as a prevailing instrument to develop a more cohesive and equal society, much more work will inevitably be needed in developing strategies to offer the highest quality of education, at the micro, meso, and macro levels [66]. The paybacks of education and training, which tackle on the domains of all the other SDGs at the level of the individual and of society, invite for a far-reaching lifelong learning model, theorized as a relationship between a person's emotional, social, and behavioral features, the accessibility and structures of education and training sources, and the responsibility of subsidiary governments [66].

\section{Examples from E=GPS and Their Role in Addressing Sub-Goal \#4.7}

In the context of the E=GPS project, public and citizenship-inclusive actions have been spread to diverse educational structures, including formal schooling from kindergarten to higher education. Programs to defend democracy, citizenship, and sustainability were also applied to other systems (labor organizations, community hubs, religious centers, municipalities, teacher and parent training organizations), where the practices implemented were dedicated to solidarity, ecological sustainability, equality, and social action. Using 
arts, sports, humanities, and other means of expression allowed for better outcomes. Furthermore, seminars and publications (manuals and chapters) on forms of collaboration and organizational compassion were implemented or are underway $[67,68]$.

From the initiatives of the project, we highlight the conference on "Transformative Education", co-organized with the Calouste Gulbenkian Foundation, Ashoka, and Mindfulness in Education. The topic was "Transformative Education", and had as guest speaker Dr. Thakur Singh Powdyel, former Minister of Education of Bhutan (2008-2013), current President of Royal Thimphu College. The conference was held at the Calouste Gulbenkian Foundation in Lisbon on 10 April 2019.

Moreover, we emphasize two webinars. First, a webinar on "Positive education", an event that opened the "1st Positive Education Meeting." It was accredited for teacher training and was co-organized in partnership by the Sá de Miranda School of Lisbon, the Optimism Club/Clube do Otimismo, and the UNESCO Chair in Education for Sustainable Global Peace, taking place in November 2020. Second, a webinar on "'Futurizing': the role of Positive Education," a virtual conference delivered within the scope of the "1st Positive Education Meeting" in November 2020. It involved around 300 teachers and school specialists.

After this initiative, the three editions of the 15-hour training course on Positive Education was delivered. The content analysis of the written open-question questionnaires (Appendix A) showed that $82 \%$ of the participants created initiatives in their schools that tackled the topics of global citizenship education, from implementing projects involving the more vulnerable part of their communities, to developing projects dedicated to optimizing civic participation from the students. This projects were developed, planned, and implemented by each teacher in his or her classroom or school, with total autonomy. Some of these projects were dedicated to the enhancement of global peace and became informal peace education initiatives. Interestingly, the use of arts (poetry, music, drawings, theater, video, among other media) was one of the means used by the teachers who participated in the Positive Education training. They used it with colleagues and teachers and parents of students to put peace education into practice, as the content analysis of the questionnaires showed (Appendix B).

\section{Education for Global Peace: Contributing to the SDG \#16}

\subsection{Peace Education}

As a global, cultural, and scientific issue, peace education has been considered a multi-disciplinary academic and ethical arena, whose studies have been used to solve problems in the context of conflict, war, and injustice - through institutions, movements, and individual skills and attitudes [69]. This is the aim of SDG \#16.

Peace education has been approached through three main points of view [70]. The first is knowledge-based peace education, understood as the information that can be communicated and trained in the school curriculum. The second, more oriented to character development, defines it as a set of abilities, values, and attitudes that are overtly transmitted as teaching resources in the school context, and can only be addressed imperceptibly and infused in educational settings. The third approach adopts a combined perspective of the two views. Accordingly, peace education is considered a process that encompasses knowledge that can be included in the school curriculum and is simultaneously an instrument that allows the training and development of skills and mindsets in students. It prepares them for interdependence, citizenship, non-violent resolution of conflicts, and global responsibility towards a just and peaceful society [70,71]. This outlook coincides with the UNESCO approach [72], which states that peace education denotes the process of promoting the knowledge, attitudes, and values necessary to prevent conflict and violence, either manifest or structural; to resolve conflicts in a peaceful manner; and to generate surroundings conducive to peaceful living. 
Reardon [71] considers that the classroom is a simulated setting where cooperative learning is the foundation for the peace education activities, in particular, where there is a potential to trigger violence or obstacles to peace (e.g., tribal, intercultural, and religious conflicts). This process applies to children, adolescents, and adults alike, and can be addressed at the intrapersonal, interpersonal, intergroup, national, or international levels. Peace education is sometimes coincident with conflict resolution education and defined as a spectrum of procedures that apply communication abilities, and ingenious and analytic thinking to resolve conflict in peaceful manners [73]. Consequently, empathy, compassion, and nonviolent communication have been relevant components of peace education [74].

\subsection{Relational and Collaborative Learning: Contributing to Accountable and Inclusive Institutions}

Relational learning involves practices that request both students and teachers to enter into a dialogue about the learning processes. This helps deconstruct the power hierarchy within the conventional teaching relationship and opens space for more collaborative experiences [75].

The social constructionist proposal for education focuses on relationships in the process of construction of the world, as opposed to the valorization of a logic in which what counts is the knowledge of the world. According to Gergen [76], we can recognize two predominant forms that are used to explain and justify the different educational practices. The author distinguished between outlooks of knowledge as endogenous (mind-centered) and exogenous (centered in the outside world). They expose a dualism between mind and social environment and overestimate the individual role in the process of knowledge acquisition over the social one. Some attempts to merge these two viewpoints can be found in the path of history (as in the case of the constructivist epistemology of Jean Piaget); however, not much progress emerged [77].

Gergen and Gergen [78] recognized two major elaborations driven by this dualism. The first refers to the pursuit of critical pedagogy that acknowledges political biases and ideological features in educational practices. This is attainable by boosting dialogue around opposed perspectives, coexistent with the appreciation these contexts' multiple realities. The second is about collaborative learning, funneled by the acknowledgement of the significance of relationships in the consideration of education as a social construction.

Dragona et al. [79] defended four main points for relational learning: (1) knowledge is situated contextually and pragmatically, considering universal and valid knowledge to be impossible without its social and cultural usefulness; (2) knowledge must be approached with critical and appreciative sensitivity, and therefore, its transmission and learning must be part of a process in which practices (action and reflection) are reconciled by meta-reflections and systematizations; (3) knowledge is action, which goes against the traditional models of teaching, transmission, and development of conceptual devices; and (4) education has a relational orientation, where the proposal is to "promote participation; facilitate the joint construction of objectives, means and ways to evaluate what has been done and makes sense to be learned; the strengthening of collective intelligence, creativity and innovation; work in groups, networks and teams; management of tensions and conflicts; and increase of the sustainability of collective efforts" [80] (p. 25).

Relational education directly influences curricula and pedagogical processes. The relational orientation assumes the question of how pedagogical practices can be transformed to become more participatory and collaborative. To make this possible, some circumstances are critical. In addition to the encounter in the school and classroom, it is also desirable to share assets. This, in turn, involves appreciation of reciprocal strengths and capabilities of each social player. It allows for the identification of existing complementarities and the understanding of the interdependence between all social parts. The dynamic balance of powers and exchanges will sanction the integration of visions and practices, and the emergence of collaboration processes around common needs, goals, and interests, generating relationships and educational processes that become inescapably multidimensional and transdisciplinary - without overlooking the differences of complex social life [81]. 


\subsection{Example from the $E=G P S$ Regarding $S D G \# 16$}

The project was responsible for the implementation of innovative community-based interventions, using participative, dialogic, and positive approaches (namely appreciative inquiry, the World Café methodology, the Jigsaw method, cooperative pedagogical practices, expressive art, sports and meditation exercises, among others). These addressed relevant topics chosen by the communities involved, such as quality of life and sustainability initiatives established by young leaders, the majority of them women. The project has invested in achieving diversity and inclusion, with a focus on intergenerational, interethnic, multinational, and multi-religious events, with special attention to marginalized youth and engaged young leaders. It created spaces and moments for them to work together around positive common aims assisted in the birth of new, peaceful, and egalitarian relationships. In addition, it gave room to the emergence of original community projects, with applications inside and outside of school premises, including diversified stakeholders and disciplines. The interventions also had implications for public policies at the local level, in terms of curricula changes and pedagogical creativity [30].

Among the encounter promoted by the project we highlight the webinar "A close look at Psychology: Interface with Institutions that support marginalized children". This virtual conference was organized by the Coordination department of the Curricular Units of Psychology at ISCSP-Universidade de Lisboa, with the support of the E=GPS UNESCO Chair. The presenters were Sónia Rodrigues, Ph.D. in psychology and external researcher at the Faculty of Psychology and Educational Sciences at the University of Porto, and Ana Conduto, a psychologist specialized in the psychology of justice. We also emphasize the webinar "Community wellbeing and cultural partner sustainability: based on urban resilience". This webinar, which took place in July 2020, was delivered within the scope of the E=GPS UNESCO Chair and of the public presentation of the Postgraduate Course in Interdisciplinary Practices and Studies for the Construction of Sustainable Peace at ISCSP and was presented by Professor Graciela Tonon and Professor Maria Laura Zulaica, from the University of Palermo, in Argentina.

In addition, we highlight the 5th Edition of the "Sharing Peace Project". The chair resumed the meetings after the pandemics, in a virtual format, maintaining the distinctive characteristic of this initiative, where inspiring national and international projects within the scope of peace, citizenship, human rights, wellbeing, mental health, and sustainability are shared. This new series already included the presentation of the following projects: (1) the LisbonProject, an NGO whose mission is to protect and integrate the lives of emigrants and refugees in the city of Lisbon; (2) the Espaço Nativa, an integrative and experimental space that intends to stimulate cooperation based on practices that foster circular economy, consumer awareness, and the promotion of cultural and educational dynamics; and (3) the Nonviolent Communication Lab, an introductory online training course for research and practice, where the principles and theoretical bases of Nonviolent Communication $(\mathrm{CNV})$ are addressed.

In what concerns the Positive Education course here under closer analysis-and as an example of the data gathered that show the possibility of promoting the three different SDGs: \#3, \#4, and \#16- the initiatives created by the teachers involved included a change in pedagogical practices more centered in relational and collaborative learning, as shown in the results of the content analysis to the 84 questionnaires, presented before and after the training. Some of the initiatives and projects imbedded processes and topics explicitly related with peace and positive conflict resolution, while others were more devoted to character development. During the second edition of the course, four of the 36 teachers worked in the same school, involving a socially and economically disadvantaged community, where one student murdered another due to a conflict among gangs. Amidst the pain and suffering, and the extreme violence drawn from this terrible episode, the community, led by these teachers, invested in mechanisms of peace and empathic relationship to transcend the conflicts and create better peaceful-oriented futures for all involved, including the families and communities outside the school. Again, data collected have 
shown that the training delivered by the E=GPS project was a useful tool to promote competencies, motivations, and practices more consonant with peace, public happiness, and global citizenship education.

\section{Summary, Conclusions, and Future Research Agenda}

Education is a highly complex concept that is difficult to articulate but needs to be spoken for. In the context of change in the civic space and the world of work-namely the demand for new skills, job disruption, threats to democracy, health risks, hazards to the environment, increased socioeconomic impoverishing, polarization, injustices, and inequalities, among others-education systems have a critical role to play in preparing the citizens of today and of the future [82]. Although there are a number of means, frequently dispersed, of addressing education, both in society at large, and inside the academia, some might contribute better to the SDGs than others. This paper presents approaches to education that can contribute to the objective of achieving the 2030 Agenda for Sustainable Development. The models hereby presented are considered fundamental for the realization of SGD \#4, but also to support the attainment of other SDGs, namely \#3 and \#16. The foundation for this strategy is supported by the development of capabilities "that allow young people to become agile, adaptive learners and citizens, equipped to navigate personal, social, academic, economic and environmental challenges" [12] (p. 4).

The Lisbon-based UNESCO project E=GPS was described in this paper and the visions and operationalization of the proposed blend of educational paradigms were illustrated through its examples. It is inspired by a sense of acceleration of the uncertainty, complexity, and fragility of the world. Furthermore, it believes that education is at the heart of transformation. Committed to researching, promoting, and implementing educational models conducive to mental health and wellbeing, public happiness, positive peace, global citizenship, ecological and social sustainability, and relational (formal and informal) education, the project is trying to explore news ways towards more holistic education values and processes. The E=GPS also departed from the belief that psychology has a very relevant role to play as an anchor discipline towards these goals, capable of integrating harmoniously different other scientific arenas, relevant to education, and assist in observing and disseminating rigorous science [31].

Among the listing of multiple initiatives developed and delivered by the E=GPS, the presentation, in more detail, of the results of a qualitative study involving 84 teachers from all school levels, from kindergarten to higher education, contributed to informing how the project is impacting the educational systems.

Results show a change in concept definition of peace and public happiness before and after the 15 hours of training, clearly indicating its impact towards a more profound and knowledgeable approach regarding the topics addressed. Thereafter, this knowledge motivated teachers to create, plan, and implement a set of autonomous and creative initiatives aimed at putting into daily practice the domains under study, from global citizenship to relational education and peaceful conflict resolution in very violent environments. This shows that these approaches can be useful and transformative, both in terms of theory-knowing about the theme from a scientific perspective-and in terms of practice- - how we can change pedagogical and relational processes, in order to address the SDGs \#3, \#4, and \#16.

For the future of the project, apart from continuing the activities initiated so far, dedicated to the scientific capacitation of the civil and academic society (namely through action-research, publications and dissemination, training for diplomas and short courses on diversified topics aimed at enhancing global and peace and sustainability, presentations on conferences at the national and international level, network increase, development and support of pedagogical materials for educational purposes, and a more clear investment in active enterprises with international partners, in particular, from Africa and South America), the Chair aims to: 
1. Spread the Positive Education course to a larger number of teachers;

2. Invest in online training on Global Peace (MOOC) with the partnership of the Open University/Universidade Aberta;

3. Create an English-speaking onsite training at ISCSP_-Universidade de Lisboa, with the support of another UNESCO Chair and the Creators of the Global Peace Index, further developing a new theoretical domain, which is the linkage between peace and positive psychology - to be held at Universidade de Lisboa;

4. Develop an index for the assessment of peace at micro and meso levels;

5. Gather the Critical Friends Committee to enhance the co-created vision of the project and its future financial supports;

6. Capitalize on educational materials and services on positive peace, global citizenship education, and public happiness, always taking into consideration the local and emergent solutions from schools, organizations, and communities;

7. Exploit research collaborations to assess the quality of educational materials and interventions;

8. Create awards for the services, products, and persons that are clearly salient on the arena of peace education and human rights; and

9. Create an online library on Peace Studies.

One of the big difficulties of this Chair so far has been finding financial support. For instance, to maintain the website, the Facebook page, to develop the monthly newsletter, and to apply for grants, we need staff that currently we cannot afford. The future projects, including creating and researching educational material, also need financial support, and this will be the major limitation of this Chair. One of the simplest solutions for this problem has been, precisely, to ask for a fee participation in the Positive Education course and the support of municipalities as partners of this training. Until now, two municipalities have shown interest in financing this course: the municipality of Cascais offered to pay for the training of 100 teachers and the municipality of Alcobaça offered to invest in the training for 600 teachers, including offering a handbook to each teacher with practical ways to implement the contents.

Through this UNESCO project, we come to value particular dimensions considered relevant for future research and practice. The vision upholds, for future research and practice, the education dimensions listed in Table 1:

Table 1. Education dimensions for future research and practice.

\begin{tabular}{|c|c|}
\hline Dimensions for Future Research and Practice & Current Obsolete Models \\
\hline $\begin{array}{c}\text { Interactions, relational goods, and co-construction } \\
\text { of knowledge }\end{array}$ & $\begin{array}{c}\text { Colonizing socially and civically anemic curricula, mostly based on } \\
\text { technical and academic competencies }\end{array}$ \\
\hline Contextually and pragmatically situated knowledge & $\begin{array}{l}\text { Educational processes taken as independent of social, economic, } \\
\text { and cultural contexts }\end{array}$ \\
\hline Collaboration and negotiation of contents & Program imposition and predefinition \\
\hline Acting towards change & Following a pre-established static stance of reality \\
\hline Socially, politically, and relationally embedded topics & Disaffected information \\
\hline $\begin{array}{c}\text { Participative building of knowledge, skills, values, } \\
\text { virtuousness, and attitudes that empower individually } \\
\text { and collectively }\end{array}$ & Traditional and disengaged models of teaching and transmission \\
\hline $\begin{array}{l}\text { A strengths-based learning system, amplifying the best in } \\
\text { people, groups, and communities }\end{array}$ & Fixing weaknesses and illiteracy of individual persons \\
\hline $\begin{array}{l}\text { Conscientization and systemic action towards peaceful } \\
\text { societies and public happiness }\end{array}$ & $\begin{array}{l}\text { Massification of thought, competition, meritocracy, and silencing of } \\
\text { collective and global endeavors }\end{array}$ \\
\hline Action-research, transformative, and civic research processes & Research void of social impact \\
\hline
\end{tabular}


The ideas presented here argued that the proposed theory of public happiness, particularly concerning relational goods, and that of global peace education and global citizenship education extends and challenges the educational practices and the policy agenda in relation to the normative target of education proposals. These can contribute to better evidence-based policies, new curricula and pedagogical methods in the education realm, and the adoption of context-specific actions with global impact. The paper suggested the need for the unification of contemporary and comprehensive models and targets for education, towards direct and undirect ethical and relevant economic, political, and social change. As indicated, education for public happiness, global peace, and citizenship is well placed to deliver a unique and vital contribution to achieving the 2030 Development Agenda and its related Sustainable Development Goals. To attain these targets, education must forge conditions for tackling crucial trials towards a more vibrant, healthy, and just civilization.

Author Contributions: Conceptualization and methodology, H.Á.M.; writing-original draft preparation, H.Á.M.; writing-review and editing, M.C. All authors have read and agreed to the published version of the manuscript.

Funding: This research received no external funding.

Informed Consent Statement: Informed consent was obtained from all subjects involved in the study.

Data Availability Statement: The data presented in this study are available on request from the corresponding author.

Acknowledgments: The authors would like to acknowledge the participation of all colleagues, staff, and students in the E=GPS project. Furthermore, the authors would like to acknowledge the support of CIAUD, through its project UIDB/04008/2020.

Conflicts of Interest: The authors declare no conflict of interest.

\section{Appendix A. Course Evaluation Questionnaire Script}

"This questionnaire is part of the Final Evaluation of the Teacher Training Course entitled Positive Education: from Science to Living Wellbeing and Peace. It intends, briefly, to evaluate the knowledge acquired, its application, and the perspectives of the students about the course-contents, format, quality of the trainer, and impact on personal and school environments.

The results obtained will be used only for the course evaluation by the trainer and for the evaluation of the Formative Action, ensuring the anonymity of the respondents. In an initial phase, there are questions about the themes under analysis in this course, followed by questions about the quality of the course and its impact.

The answers should be thoughtful, sincere, and synthetic to all questions.

1. Following your participation in the course, do you think your definition of Positive Education has changed compared to the one given in the questionnaire at the beginning of the course? How would you define it today?

2. Following the participation in the course, do you think that you have changed your definition of Happiness, compared to the one given in the questionnaire at the beginning of the course? How would you define it today?

3. Following your participation in the course, do you think your definition of Peace has changed compared to the one given in the questionnaire at the beginning of the course? How would you define it today?

4. Do you consider that, after the learnings acquired in the course, you are doing something different to promote your happiness and wellbeing? If so, what?

5. What have you done differently for the happiness of your students, as a result of what you learned in the course?

6. In what ways do you think you are contributing to peace after participating in this course? Has anything changed in the way you consider that you are promoting peace? If so, what? 
7. What is now the smallest step that you believe will increase your personal happiness? Have you changed since the beginning of the course? If so, why have you changed?

8. After the course, what do you consider to be the smallest steps that you believe will increase happiness in your school community (taking into account students, teachers, non-teaching staff, and students' families)?

9. Were the dreams and wishes you had for this training fulfilled? If so, which ones were fulfilled?

10. What did you appreciate most about this course (in terms of content, structure, format, duration, pedagogy, science, interpersonal relations...)?

11. What would you have preferred to have been different in order for you to be more satisfied with the course (in terms of content, structure, format, duration, pedagogy, science, interpersonal relations...)?

12. Please rate the quality of the trainer, indicating virtues and areas for improvement.

13. What have you done (or are you doing) differently in your personal and professional life, as a consequence of this course?

14. What and how do you hope to put into practice in the future, based on what you have learned in these 15 training hours?

15. What resources do you think you will need to be able to realize the course learnings (yours, your school, the scientific community, politicians, etc...)?

16. What suggestions would you like to leave to the course organizers for future replication of the course with other teachers and/or support and continuity for the participants in this first training?

17. What else would you like to add?

A deep thank you for your precious participation. July 2021."

\section{Appendix B. Analysis of Qualitative Responses to the Course Evaluation Questionnaires}

The following is a qualitative analysis of the responses to the final course evaluation questionnaires, which were completed individually. They comprised 17 open-ended questions (see Appendix A), which were divided into three major areas, namely:

1. Questions that identified potential changes in trainees' knowledge of the definition and description of the domains and theoretical concepts addressed, when compared to the beginning of the course (trainees had answered an initial questionnaire about their knowledge regarding these topics, what training they had or did not have on them, what they wanted to learn ... );

2. Questions regarding the applications that the participating teachers have made or plan to make of the course contents within their professional activity and personal experience and questions regarding suggestions for the future and continuity in the implementation of the course contents and the manual of the program that was made available;

3. Evaluation issues of the course itself (contents, objectives, pedagogical methods, qualities and limitations of the trainer, time format-number of hours, schedules...and concerning the teaching-learning process and dissemination of learning).

We now analyze the answers to all the questions, based on the dimensions described. As for the assessment of the answers to point (1), which corresponded to three questions (one about the concept of Positive Education, another about the concept of Happiness, and another about the concept of Peace), some trainees indicated that they had changed their perspective and/or definition of the concepts mentioned, others indicated that they had kept that perspective, but had expanded it, and still others pointed out that they defined them in the same way at the end of the course, compared to the definition and understanding presented in the questionnaire at the beginning. 
The fact that we had in the group trainees with no training in the topics covered and others with post-graduate training in the area (which had been taught and coordinated by the same trainer of this course), greatly justifies these results, as there were participants with total ignorance of the contents to be taught and others with many hours of previous training in the area, who chose to take the course to update themselves and follow the program presented in the manual, of which they were unaware and wanted to apply to their students.

Additionally, we verified that the theoretical knowledge of the concepts, after the training, was evidenced in the answers given to the questions, even including references to authors, scientific definitions, and specific psychological variables. Examples of answers are given below:

- "Yes, it did. The main changes have to do with helping students raise their selfknowledge, making them feel good in their "skin", being able to implement wellness functioning in the class dynamics, and being able to help them understand what it is to live with purpose, doing good."

- "What I learned in this course has transformed the way I understand and resolve my relationship with students (and other people I come across in a work context) in difficult times and enabled me to empower my role as a vehicle for peace and happiness. This last sentence translates my definition of Positive Education-it is each of us the agent of change and we should be aware of it."

- "It changed, because I didn't think happiness could be associated with growth mindset. I learned that growth mindset can't be dissociated from satisfaction with life."

- "At the beginning of this course I did not consider Happiness as a debatable issue that could be studied. Even more, I never hypothesized to make Happiness a content that could be addressed in the classroom. Today I see that I was completely wrong; I find myself daily thinking about my own happiness and wondering about its existence in my life."

- "Up until this point I have not considered talking about Peace in the classroom. While it is something we all seek and want for our lives, we need to equip ourselves with the knowledge to contextualize it in the classroom."

- $\quad$ "Yes, I think I've changed my mind a little. Because Positive Education is not only what we intend to transmit and "teach" to others, in this case our students, but it must also be centered in our own person. If we don't believe in ourselves first and if we are not well with ourselves we will hardly pass this message of Positivism to the other. Thus Positive Education can be defined as a form of Wellbeing with myself and others."

- $\quad$ "I stick to the same definition. The concept of happiness has been studied by many researchers from all continents. There are researchers who define happiness as a subjective wellbeing, others as flourishing, and others define it as a psychological wellbeing. Hedonic happiness is focused on the person and their own pleasure and eudaimonic happiness is concerned with relationships with others."

- " "I keep thinking of Peace as tranquility, emotional wellbeing. I reflected that achieving that Peace is really a path and a will that must be lived and felt, in the different spheres of our lives."

- "Yes, a little bit. Educating consciously, promoting balance, understanding, focusing on the best in the student. Acquiring knowledge by strengthening their character strengths, affection, respect for differences. Propitiating relational assets with others and the environment."

- $\quad$ "I don't think I have changed the concept much, I just feel more sure of how to find it and live it. I feel that right now I am more able to value the present and look for happiness in the small moments experienced. Peace is still synonymous with inner tranquility of wellbeing."

With regard to point (2), concerning the applications and changes made during and after the course, through the content of the course-both in the school context and in personal life-there was an almost unanimous positive response, with practically all participants indicating that they were already making changes, either in one field of school 
and pedagogical action, or in the strictly personal and family field, or in both; that they had a clear intention to change in terms of behavior; or that they had changed, not yet their actions, but their perception of themselves and their practices; or that they were continuing these practices in a broader, deeper, or more conscious way. The response from the participants who claimed to be continuing what they were already doing corresponded to those who had already had previous post-graduate training at the Universidade de Lisboa on these themes. It was asked not only if they had made transformations, but if so, which ones.

The evaluation of this paragraph on implementation comprised four questions from the survey, followed by a question more focused on future action intentions, which is addressed below. Here are some sample answers from this evaluative dimension relating to point (2).

- "Yes. I started to be able to verbalize quite a bit more the positive feelings I have for others and also to value the positive acts of the other person quite a bit more, through true praise."

- "I try to be more attentive to their needs not only learning but emotional. We have been doing at least once a week a time of expressing the emotions of the week especially connected to this difficult time we are going through and teaching them to focus on their breathing."

- "By valuing the positive aspects of others as well as their actions and devaluing the less positive. By not judging, but forgiving. Always being a friend not an enemy. Always having a feeling of kindness toward others."

- "I consider it important that coming into contact for the first time with this dimension of psychology has brought me a knowledge that I intend to deepen. In this posttraining phase, I provide myself with moments of apprehension and self-analysis. I try to change states of mind and understand the state I am in in relation to myself and in relation to others."

- "I try to be more positive in my personal and professional daily life. I continue to be cheerful and friendly in the classroom and provide my students with a calm and peaceful environment so that they can learn smoothly. I really enjoy communicating, sharing experiences and knowledge, and giving praise. I also appreciate hearing what students have to tell and their opinions."

- "I would say yes. I have been reflecting more on these issues and trying to be more attentive to the way I think and speak, of and with others. Although sometimes it is hard for me to be positive with myself, I make an effort to find in myself this Happiness and Wellbeing that I want so much to transmit to others. As I said earlier I first need to change my Self."

- "I promoted and streamlined activities and conversations in which students can feel that we are happy when we make others happy. I took advantage of the Christmas season to make them aware of issues related to Solidarity and Family."

- "Participating in this course has further strengthened this desire of mine to promote Peace among those I have the privilege to live with. I continue to be, I think, a person who tries to avoid conflict among others either through conversation or through actions, giving opportunity for exchange of ideas and points of view."

- 'I don't think I've changed much, but I feel like I want to improve my self-esteem. I always feel that I can be and do better, but I also have to want to. And to WANT is not to stay in my comfort zone and wait for something to happen. It's about taking action. My first step is going to be taking care of my fitness..."

- "Through sharing this knowledge, with gestures of affection, of understanding, of empathy. Applying the strengths of character in the classroom. And continue to apply my project 'the best of me'."

- "Through this course I was able to bind my daily practice of gratitude, forgiveness a bit more and refine slightly visualizing obstacles as blessings." 
- "After completing this training I had few opportunities to apply the knowledge in my classes, as I only teach one day a week, however, I have thought about my relationship with my students, the way I dialogue. I have changed the way I show myself to students, trying to show them who I am, effectively. That transparency promotes a better relationship between us."

- "My way of being is peaceful by default. What has effectively changed, is my state of consciousness, I have awakened to a reality that I observe constantly."

- "I have gained awareness that, despite the difficulty arising from having too many students per class, I should strive to take more account of their interests and difficulties, motivating them to be more open towards the people they relate to. I have shared with them the learnings I have made and my logbook, where I refer to them and show them phrases and thoughts I have used in class with them, showing them how much I have cared about helping them grow and become principled people they will take with them into their lives. I encourage them to be happy, with what they have and what they are."

- "It will be all the steps I can take to promote a good atmosphere at school, making the members of the educational community feel good in their 'second' home. Be nice, be available and collaborate with everyone, get involved in solidarity projects."

- "As I consider myself and see myself as a positive person who cares about others, I don't feel that I have changed many things, perhaps I have consolidated them. I made a point of mentioning more often that I like the people around me, I want to contribute, through my discipline and my sharing, to the growth of my students, motivating them to seek happiness and peace. I value, more and more, the positive aspects of life and I try to make sure that those around me do the same. I continue to involve myself and others/students in solidarity projects."

- "Throughout the training sessions, I have always been linking the learning with philosophical content that I cover in my classes. I intend to use the work 'Personal Wellness Lessons/Positive Psychology in Action,' select some of them and 'apply' them to the students. A few years ago, I provided my students with some 'Citizenship Education' classes, promoted by volunteers from the Food Bank Against Hunger, which addressed topics already associated with Positive Education."

- "There has been a small improvement at the level of my personal transformation and new ideas have emerged to make more innovations in my teaching practice."

- "I'm improving my gratitude and seeing more opportunities where I see obstacles, feeling that it's urgent to change my life, and regularly creating small steps of happiness."

Still within point (2) followed a question about future actions, namely from what the students believed to be the smallest step to initiate or strengthen changes in the area of promoting wellbeing, peace, and positive education. The answers cover more personal dimensions - what each teacher will do differently, in his/her role as a teacher or, in general, as a person-and others more about involving the students in this process of promoting happiness and peace through positive education. Examples of responses follow.

- "The smallest step that could increase my happiness is to remember every moment that it is fundamental to live in the present moment. The course reinforces this awareness. When I focus my thoughts on the past or the future I get very anxious. I am constantly doing the exercise of turning my mind to the present moment."

- "To be able to start this journey that takes me and those around me on the path to happiness and wellbeing. To develop in my students hope."

- "I hope, in the future, to include the principles of positive education more and more in my classes."

- "My only goal, as a teacher for many years now, is to bring happiness to the school community. I keep trying, always aware that I do what I can and that some people simply don't want to be happy." 
- "Teachers who are more attentive, kinder, happier, and in a better mood will certainly make everyone else with whom they interact in their daily school life happier. I believe that in the smallest relationship we establish with any element of the school community, the fact that we ourselves are happier will contribute to increase the happiness of others. There is, however, a huge job to be done to improve the conditions for happiness to happen in small daily acts at school. I work in a school with very precarious facilities, which has been waiting for construction since I've been there for twenty-two years, yet it is a school that students look for, where they feel good, where they are happy, particularly high school students. Since its opening, integration criteria have been important to create a school culture that still reflects this. Presently, after profound changes in the Direction, I fear that this scenario will change and with it, I will end my cycle there, because I feel it makes me unhappy (I made this discovery very recently)."

- "I am on the path of seeking my inner path internalization so that I become a calmer, less anxious person, able to live the present more consciously. Learning to focus on the happy moments, and I try to eat a more balanced diet, but most of all do the six or seven hours of a good little sleep."

- "I am thinking of following some lessons from the manual and for that I am currently reading and selecting those that I consider most important taking into account the characteristics of the class. We will see how the students will react (although I don't have much time). On the question of the resources needed to implement and expand the program in school and personal terms in the future, the opinions reflect various aspects, from more curricular aspects and ministerial management decisions, to more operational aspects in schools and schedules, and more psychological and personal aspects. Here are some examples."

- "Since I teach high school, in exam years I needed to make the Ministry of Education aware of decreasing the curriculum load so we could have more time to dedicate to emotions."

- "Depending on the activities/projects I am/will be involved in, I will need various resources, but I can usually access the ones I need. The Cascais City Council has been very collaborative with the School."

- "Maybe a less extensive program and less competitive teaching to have time to reflect and listen more to my students. A review of the curriculum, with new subjects that teach/address other areas of knowledge would also be interesting."

Turning now to the analysis of the more specific questions relating to point (3), a highly positive evaluation was noted regarding the fulfillment of expectations and dreams in relation to the course, with all trainees praising the fact that it met or exceeded their expectations. Here are examples of responses.

- "Yes, it was a training in which it was possible to have a lot of sharing and exchange of ideas, and I find that very enriching. We had the opportunity to meet people and establish bonds with them. The knowledge transmitted allows us to try to be better people. I learned a lot of new things, I remembered learnings, sometimes a little 'forgotten,' (for lack of time to stop and calm down) and I want to 'improve' myself as a person."

- "The biggest one was accomplished, which was to quench my curiosity about Positive Education time: what it is, what it is based on, how it is applied. Plus, how I can be happier and help others to be happier."

- "I was curious about the principles of positive psychology. I had read some authors before, but nothing conclusive. I found it interesting and yes, it satisfied my curiosity.

- "I think the expectations have been met; now it's up to me to internalize and continue to build these and other dreams to keep moving forward always in the realization of my happiness and that of the students." 
Still on point (3), the answers concerning the evaluation of the course itself and the quality of the trainer were again deeply appreciative, as can be seen in some of the responses below. More than one participant indicated that they would like the course to have more hours, and also that it should have a face-to-face or hybrid dimension. Apart from that, the evaluations are deeply constructive.

- $\quad$ "All the contents were quite aggrandizing, I liked everything, but what stood out to me the most was the capacity that the whole group had to produce relational goods together. This was extraordinarily rich, because all the elements of the group complemented each other, it seemed as if they had known each other for a long time. It is obvious that all this was only possible due to the great mastery of the trainer, the exceptional way she conducted the whole course, how she transmitted her knowledge, how she elevated, valued and trusted each trainee, which allowed the production of the excellent activities that were shared. The entire course was held in a very welcoming environment. All the contents were explained step by step, I highlight the fact that the training was very well structured, as well as the quantity and quality of the contents taught, which was very enriching."

- "In terms of duration I felt it could go on longer. It passed quickly, I wished to continue there."

- "About the trainer, it was a blessing the way we were received in each session, the trainer's smile as well as her confidence in each trainee were an asset for the group to go further with each passing session. Each email she sent us was always full of very motivating words. I thank the trainer for the fact that her calmness and ability to motivate the trainees during the whole course was very evident. She proved to be an extraordinary example to follow, because her posture and confidence in the group allowed the production of works of excellence that were shared, I was amazed at the productions of each colleague. The trainer always performed her role with a high professional pride."

- $\quad$ "I think the course is well structured and should be kept in this format. As for the continuity of the course we attend, meeting once a month, that seems very good to me."

- "I didn't expect such an interesting working group, so in unison, with such a committed trainer. I appreciated the distance-learning format, which worked fully, in the sense that the sense of group, of sharing, was maintained, allowing the perfect transmission of content. The pedagogy applied was very adequate, as were the work suggestions at the end of each session."

- "What I appreciated most was the focus that the trainer was able to give to relational assets, managing to establish among the trainees a real sense of wellbeing and sense of belonging to the group, through the creation of bonds of affection among us."

- "I especially appreciated the content, but especially the strategy namely the sharing moments in the rooms, which were also moments to reflect on ourselves, which is very difficult in everyday life."

- "I appreciated the level of participation, the satisfaction of all, the preparation of the logbooks and seeing and appreciating others; the practical side and the prospects for change; the positive achievement in perspective. Also the manual that comes with the course, which makes the training more continuous."

- "It's a course where each session went by quickly, where you want to continue there, so its duration can be longer."

- "The support for the participants of this training is important. It would be interesting to have applied a lesson among the group to understand the structure of the lesson, the doubts or difficulties that may exist."

- "The trainer was excellent for the way she encouraged us, for sharing and how she communicated the knowledge, how she always valued everyone's work. I only have one word to express what I feel: GRATITUDE." 
- "I would like the course to be 50 hours long so that the topics could be developed with more time and so that we could explore the Manual with the help of the trainer and share feedback with the other trainees."

\section{References}

1. Baker, L.; Wright, S.; Mylopoulos, M.; Kulasegaram, M.; Ng, S. Aligning and applying the paradigms and practices of education. Acad. Med. 2019, 94, 1060. [CrossRef]

2. Fagerlind, I.; Saha, L. Education and National Development; Pergamon Press: Oxford, UK, 1983; pp. 1-302.

3. Saliceti, F. Educate for creativity: New educational strategies. Procedia Soc. Behav. Sci. 2015, 197, 1174-1178. [CrossRef]

4. Ng, S.; Baker, L.; Friesen, F. Teaching for Transformation. An Online Supplement. Available online: https://www.teachingfortransformation. $\mathrm{com} /$ (accessed on 20 May 2020).

5. UNESCO. General Assembly. Available online: https://en.unesco.org/gem-report/report/2015/education-all-2000--2015 -achievements-and-challenges (accessed on 12 June 2020).

6. EFA. Global Monitoring Report. Education for all 2000-2015: Achievements and Challenges: The 2015 Global Monitoring. Available online: https:/ / unesdoc.unesco.org/ark:/48223/pf0000232565_por (accessed on 24 January 2020).

7. United Nations Decade for Sustainable Development. Available online: https://en.unesco.org/themes/education-sustainabledevelopment/what-is-esd/un.decade-of-esd (accessed on 5 May 2020).

8. Incheon Declaration and Frame for Action. Available online: https://iite.unesco.org/publications/education-2030-incheondeclaration-framework-action-towards-inclusive-equitable-quality-education-lifelong-learning/ (accessed on 24 May 2020).

9. UNESCO. Global Education Monitoring Report 2019: Migration, Displacement and Education: Building Bridges, Not Walls; UNESCO: Paris, France, 2018; p. i-415.

10. World Economic Forum (WEF). Platform for Shaping the Future of the New Economy and Society Schools of the Future Defining New Models of Education for the Fourth Industrial Revolution. Available online: http://www3.weforum.org/docs/WEF_ Schools_of_the_Future_Report_2019.pdf (accessed on 5 March 2020).

11. Biester, U.; Mehlmann, M. A Transformative Edge: Knowledge, Inspiration and Experiences for Educators of Adults; Transformations Hosts International Publications: Berlin, Germany, 2020; pp. 1-426.

12. UNICEF Education Strategy 2019-2030: Every Child Learns. Available online: https://www.unicef.org/reports/UNICEFeducation-strategy-2019--2030 (accessed on 5 June 2020).

13. Global Compact on Education. Available online: https://www.educationglobalcompact.org/en/global-compact-on-education/ (accessed on 8 May 2020).

14. Watkins, D. Pope Calls for Educational Alliance to Promote Care for Common Home. Available online: https:/ /www.vaticannews. $\mathrm{va} / \mathrm{en} /$ pope/news/2019--09/pope-francis-educational-alliance-new-humanism.html (accessed on 21 May 2021).

15. Millennium Development Goals (MDGs). Available online: https://www.un.org/millenniumgoals / (accessed on 30 June 2020).

16. SDG Compass. Available online: https://sdgcompass.org/sdgs/sdg-3/ (accessed on 5 July 2020).

17. Hidaka, B.H. Depression as a disease of modernity: Explanations for increasing prevalence. J Affect. Disord. 2012, 140, 205-214. [CrossRef] [PubMed]

18. Ohrnberger, J.; Fichera, E.; Sutton, M. The dynamics of physical and mental health in the older population. JEoA 2017, 9, 52-62. [CrossRef] [PubMed]

19. Melrose, S.; Park, C.; Perry, B. Teaching Health Professionals Online: Frameworks and Strategies; AU Press: Athabasca, AB, Canada, 2013; pp. 1-173.

20. Clark, M.C.; Wilson, A.L. Context and rationality in Mezirow's Theory of Transformational Learning. Adult Educ. Q. 1991, 41, 75-91. [CrossRef]

21. Mezirow, J. A transformation theory of adult learning. In Proceedings of the 31st Annual Adult Education Research Conference, Athens, GA, USA, 18-20 May; Kleiber, P., Tisdell, L., Eds.; University of Georgia Press: Athens, GA, USA, 1990; pp. 141-146.

22. Taylor, E.W.; Cranton, P. The Handbook of Transformative Learning: Theory, Research and Practice; Jossey-Bass: San Francisco, CA, USA, 2012; pp. 1-624.

23. UNESCO. Roadmap for Implementing the Global Action Programme on Education for Sustainable Development. Available online: https: / / unesdoc.unesco.org/ark:/48223/pf0000230514 (accessed on 5 June 2020).

24. Manteaw, B.O. When businesses go to school: Neoliberalism and education for sustainable development. JESD 2008, 2, 119-126. [CrossRef]

25. Bruni, L. A Ferida do Outro: Economia e Relações Humanas; Cidade Nova: Abrigada, Portugal, 2010; pp. 1-213.

26. Richardson, F.C.; Guignon, C.B. Positive psychology and philosophy of social science. Theory Psychol. 2008, 18, 605-627. [CrossRef]

27. Christopher, J.C.; Hickinbottom, S. Positive psychology, ethnocentrism, and the disguised ideology of individualism. Theory Psychol. 2008, 18, 563-589. [CrossRef]

28. Delsen, L. Education and Training: From Consumption Goods to Investment Goods. (NiCE Working Paper 07-102); NICE: Nijmegen, The Netherlands, 2007; pp. 1-26.

29. Stark, L. "We're Trying to Create a Different World": Educator Organizing in Social Justice Caucuses. Ph.D. Thesis, University of Virginia, Charlottesville, VA, USA, August 2019.

30. Marujo, H.Á.; Neto, L.M. Creating peace: The education for Global Peace Sustainability Project. Gaudium Sciendi 2017, 12, 51-74. 
31. Marujo, H.Á. Annual Report of the UNESCO Chair on Education for Global Peace Sustainability; Universidade de Lisboa: Lisboa, Portugal, 2020.

32. Marujo, H.Á.; Neto, L.M. Exploring the concept and practices of Felicitas Publica at Lisbon University: A community and relational approach to well-being. In Community Quality of Life and Well-Being in Latin Countries; Tonon, G., Ed.; Springer: Dordrecht, The Netherlands, 2017; pp. 67-89.

33. Nussbaum, M. Not for Profit: Why Democracy Needs the Humanities; Princeton University Press: Princeton, NJ, USA, 2010; pp. 1-192.

34. Cerro Santamaría, G. Challenges and drawbacks in the marketisation of higher education within neoliberalism. Rev. Eur. Stud. 2019, 12, 22-38. [CrossRef]

35. Becchetti, L.; Pelloni, A.; Rossetti, F. Relational goods, sociability, and happiness. Kyklos 2008, 61, 343-363. [CrossRef]

36. Camicia, S.; Franklin, B. What type of global community and citizenship? Tangled discourses of neoliberalism and critical democracy in curriculum and its reform. Glob. Soc. Educ. 2011, 9, 311-322. [CrossRef]

37. Waters, L. Searching for wellbeing in schools: A new framework to guide the science of positive education. J. Educ. Psychol. Res. 2019, 1, 1-8.

38. Norrish, J. Positive Education: The Geelong Grammar School Journey. Oxford Scholarship Online. Available online: https: / / www.oxfordscholarship.com/view/10.1093/acprof:oso/9780198702580.001.0001/acprof-9780198702580 (accessed on 5 May 2020).

39. Peterson, C.; Seligman, M.E.P. Character Strengths and Virtues: A Handbook and Classification; Oxford University Press: New York, NY, USA, 2004; pp. 1-800.

40. Linkins, M.; Niemic, R.; Gilham, G.; Mayerson, D. Through the lens of strength: A framework for educating the heart. J. Posit. Psychol. 2014, 10, 64-68. [CrossRef]

41. Moore, C. What is Positive Education and How Can We Apply It? Available online: https://positivepsychology.com/what-ispositive-education/ (accessed on 25 June 2020).

42. Heckman, J.J. Policies to foster human capital. Res. Econ. 2000, 54, 3-56. [CrossRef]

43. Clark, A. Four decades of the economics of happiness: Where next? Rev. Income Wealth 2018, 64, 245-269. [CrossRef]

44. Thoits, P.; Hewitt, L.N. Volunteer work and well-being. J. Health Soc. Behav. 2001, 42, 115-131. [CrossRef] [PubMed]

45. Flavin, P.; Keane, M.J. Life satisfaction and political participation: Evidence from the United States. J. Happiness Stud. 2012, 13, 63-78. [CrossRef]

46. De Neve, J.; Diener, E.; Tay, L.; Xuereb, C. The Objective Benefits of Subjective Well-Being. In World Happiness Report 2013; Helliwell, J., Layard, R., Sachs, J., Eds.; UN Sustainable Development Solutions Network: New York, NY, USA, 2013 ; pp. 1-35.

47. Hogan, M.J. Collaborative positive psychology: Solidarity, meaning, resilience, wellbeing, and virtue in a time of crisis. Int. Rev. Psychiatry 2020, 32, 698-712. [CrossRef] [PubMed]

48. White, S.C. Relational wellbeing: Re-centering the politics of happiness, policy and the self. Policy Politics 2017, 45, 121-136. [CrossRef]

49. Wissing, M.P. Embracing well-being in diverse contexts: The third wave of Positive Psychology. In Proceedings of the First Africa Positive Psychology Conference, Potchefstroom, South Africa, 4-7 April 2018.

50. Roodt, V. On public happiness. S. Afr. J. Philos. 2014, 33, 455-467. [CrossRef]

51. Bruni, L.; Zamagni, S. Civil Economy: Efficiency, Equity, Public Happiness; Peter Lang: Bern, Switzerland, 2007 ; pp. 1-259.

52. Marujo, H.Á.; Neto, L.M. Felicitas Publica and community well-being: Nourishing relational goods through dialogic conversations between deprived and privileged populations. J. Psychol. Afr. 2014, 24, 161-181. [CrossRef]

53. Frey, B.S.; Luechinger, S.; Stutzer, A. The life satisfaction approach to environmental valuation. Annu. Rev. Resour. Econ. 2010, 2, 139-160. [CrossRef]

54. Bartolini, S. Relational goods. In Encyclopedia of Quality of Life and Well-Being Research; Michalos, A.C., Ed.; Springer: Dordrecht, The Netherlands, 2014; pp. 5428-5429.

55. Gui, B.; Sugden, R. Why interpersonal relations matter for economics. In Economics and Social Interactions, Accounting for Interpersonal Relations; Gui, B., Sugden, R., Eds.; Cambridge University Press: Cambridge, MA, USA, 2005 ; pp. 1-22.

56. Putnam, R. Bowling Alone: The Collapse and Revival of American Community; Simon and Schuster: New York, NY, USA, 2000; pp. $1-550$.

57. Gui, B.; Stanca, L. Happiness and relational goods: Well-being and interpersonal relations in the economic sphere. Int. Rev. Econ. 2010, 57, 105-118. [CrossRef]

58. Ness, O.; Heimburg, D.V. Collaborative Action Research: Co-constructing social change for the common good. In The SAGE Handbook of Social Constructionist Practice; McNamee, S., Gergen, M.M., Camargo-Borges, C., Eds.; SAGE Publications: Thousand Oaks, CA, USA, 2020; pp. 34-45.

59. Nikel, J.; Iowe, J. Talking of fabric: A multi-dimensional model of quality in education. Compare 2010, 40, 589-605. [CrossRef]

60. Tawil, S.; Akkari, A.; Macedo, B. Beyond the conceptual maze. Approaches to quality in education. In UNESCO Education Research and Foresight; ERF Discussion Papers, No. 2; UNESCO: Paris, France, 2011; Available online: https://archive-ouverte.unige.ch/ unige:20233 (accessed on 21 May 2021).

61. Moore, J. Barriers and pathways to creating sustainability education programs: Moving from rhetoric to reality. Environ. Educ. Res. 2005, 11, 537-555. [CrossRef] 
62. Ferkany, M.; Whyte, K.P. The importance of participatory virtues in the future of environmental education. J. Agric. Environ. Ethics 2011, 3, 419-434. [CrossRef]

63. Sant, E. Democratic education: A theoretical review (2006-2017). Rev. Educ. Res. 2019, 89, 655-696. [CrossRef]

64. Pais, A.; Costa, M. An ideology critique of global citizenship education. Crit. Stud. Educ. 2020, 61, 1-16. [CrossRef]

65. Banks, J.A. Failed citizenship and transformative civic education. Educ. Res. J. 2017, 46, 366-377. [CrossRef]

66. Boeren, E. Understanding Sustainable Development Goal (SDG) 4 on "quality education" from micro, meso and macro perspectives. Int. Rev. Educ. 2019, 65, 277-294. [CrossRef]

67. Araújo, M.L.; Simpson, A.V.; Marujo, H.Á.; Lopes, M.P. Selfless and strategic, interpersonal and institutional: A continuum of paradoxical organizational compassion dimensions. J. Polit. Power 2019, 12, 16-39. [CrossRef]

68. Marujo, H.Á.; Neto, L.M.; Wissing, M. Conversations as carriers of meaning to the common good. In Quality of Life in Africa; Eloff, I., Ed.; Springer: Dordrecht, The Netherlands, 2019; pp. 113-121.

69. Cremin, P. Promoting education for peace. In Education for Peace; Cremin, P., Ed.; Irish Peace Institute: Limerick, Ireland, 1993; pp. 1-130.

70. Wahyudin, D. Peace education curriculum in the context of education sustainable development (ESD). JSDER 2018, 2, 23-32. [CrossRef]

71. Reardon, B.A. Comprehensive Peace Education: Educating for Global Responsibility; Teachers College Press: New York, NY, USA, 1988; pp. $1-121$.

72. Delors, J. Educação um Tesouro a Descobrir—Relatório para a Unesco da Comissão Internacional sobre Educação para o Século XXI; Edições Asa: Porto, Portugal, 1999; pp. 1-288.

73. Salomon, G. The nature of peace education: Not all programs are created equal. In Peace Education: The Concept, Principles, and Practices Around the World; Salomon, G., Nevo, B., Eds.; Lawrence Erlbaum Associates: London, UK, 2002 ; pp. 34-48.

74. Galtung, J. Peace: A Peace Practitioner's Guide. University for Peace. Available online: https://www.upeace.org/files/Ideas\%20 for\%20Peace/Ideas\%20for\%20Peace\%20Vol.\%2013.pdf (accessed on 24 April 2020).

75. Taos Institute. Relational Learning in Education. Available online: https://www.taosinstitute.net/relational-learning-ineducation (accessed on 18 September 2019).

76. Gergen, K.J. Relational Being: Beyond Self and Community; Oxford University Press: Oxford, UK, 2009 ; pp. 1-418.

77. Gergen, K.J. Relational being: A brief introduction. J. Constr. Psychol. 2011, 24, 280-282. [CrossRef]

78. Gergen, K.J.; Gergen, M. Social Construction: Entering the Dialogue; Taos Institute Publications: Chagrin Falls, OH, USA, 2004; pp. $1-100$.

79. Dragona, T.; Gergen, K.J.; McNamee, S.; Tseliou, E. Education as Social Construction: Contributions to Theory, Research and Practice; WorldShare Books; Taos Institute Publications: Chagrin Falls, OH, USA, 2015; pp. 315-335.

80. Fuks, H. Aprendizagem e trabalho cooperativo no ambiente AulaNet. RBIE 2015, 6, 53-74.

81. De Andreotti, V.O. Soft versus critical global citizenship education. In Development Education in Policy and Practice; McCloskey, S., Ed.; Palgrave Macmillan: London, UK, 2014; pp. 21-31.

82. Hastings, M. Neoliberalism and Education. Oxford Research Encyclopedia of Education. Available online: https://oxfordre. com/education/view/10.1093/acrefore/9780190264093.001.0001/acrefore-9780190264093-e-404 (accessed on 9 May 2020). 